\title{
Upaya Meningkatkan Kinerja Guru dalam Mengajar Melalui Reward dan Punishment Oleh Kepala UPTD SD Negeri 01 Suliki Kecamatan Suliki
}

\author{
ARFI \\ Kepala Sekolah UPTD SDN 01 Suliki \\ Email:
}

\begin{abstract}
ABSTRAK
Penelitian ini berawal dari permasalahan guru yang dalam melakukan pekerjaannya dalam mengajar memiliki rasa kurang bertanggung jawab. Selain itu ada juga guru yang sering bolos, tidak membuat administrasi mengajar dan tidak mematuhi perintah. Dengan adanya guru yang mempunyai kinerja rendah, akan sulit untuk mencapai hasil seperti yang diharapkan. Penelitian ini merupakan penelitian tindakan sekolah dengan menggunakan pendekatan kualitatif. Penelitian ini dilaksanakan pada guru-guru UPTD SD Negeri 01 Suliki Kecamatan Suliki yang berjumlah 8 (delapan) orang guru. Instrumen yang digunakan untuk mengumpulkan data berupa lembar observasi dan dokumentasi. Data yang diperoleh dalam penelitian dianalis dengan menggunakan analisis data kualitatif dan kuantitatif. Penelitian ini dilaksanakan dalam dua kali siklus dansetiap siklusterdiri dari dua pertemuan. Hasil penelitian dari setiap siklus penerapan Reward dan Punishment efektif untuk meningkatkan kinerja guru dikelas pada kegiatan belajar mengajar. Data yang diperoleh menunjukan bahwa setelah diadakan penerapan tindakan berupa Reward dan Punishment, pada siklus I sudah ada peningkatan kinerja guru dari pertemuan 1 ke pertemuan 2 namun masih belum mampu mencapai nilai minimal yang ditetapkan. Namun, setelah dilakukan reward and punishment lebih ditingkatkan maka pada siklus II sudah seluruh guru mampu meningkatkan kinerjanya. Dengan demikian dapat disimpulkan bahwa penerapan Reward dan Punishment dapat meningkat kinerja guru dalam proses belajar mengajar di UPTD SD Negeri 01 Suliki Kecamatan Suliki.
\end{abstract}

\section{Kata Kunci : Kinerja Guru, Reward and Punishment}

\section{PENDAHULUAN}

Pendidikan adalah wahana untuk mencetak generasi muda yang sangat penting bagi masa depan negeri ini. Tanpa ada pendidikan yang baik dan berkualitas, tentu saja negeri ini akan terancam karena anak mudanya dididik secara serampangan dan tidak sesuai dengan nafas kemajuan zaman yang semakin cepat ini. Dan untuk mendapatkan pendidikan yang berkualitas tentu saja segala pihak yang berkompeten di dalamnya harus bekerja keras untuk memberikan yang terbaik dalam memajukan pendidikan.

Perkembangan global dan era informasi memacu bangsa Indonesia untuk meningkatkan kualitas sumber daya manusia, karena dengan sumber daya manusia yang berkualitas merupakan modal utama dalam pembangunan di segala bidang sehingga diharapkan bangsa Indonesia dengan sumber daya manusianya dapat bersaing dengan bangsa lain yang lebih maju.
Dalam mengembangkan dan meningkatkan kualitas sumber daya manusia, pendidikan memiliki peranan yang sangat penting, yang diperlukan bagi pembangunan di segala bidang kehidupan bangsa, terutama mempersiapkan peserta didik menjadi aktor IPTEK yang mampu menampilkan kemampuan dirinya, sebagai sosok manusia Indonesia yang tangguh, kreatif, mandiri, dan profesional di bidangnya.

Tenaga guru adalah salah satu tenaga kependidikan yang mempunyai peran sebagai salah satu faktor penentu keberhasilan tujuan pendidikan, karena guru yang langsung bersinggungan dengan peserta didik, untuk memberikan bimbingan yang akan menghasilkan tamatan yang diharapkan. Guru merupakan sumber daya manusia yang menjadi perencana, pelaku dan penentu tercapainya tujuan organisasi.

Guru merupakan tulang punggung dalam kegiatan pendidikan terutama yang berkaitan 
dengan kegiatan proses belajar mengajar. Tanpa adanya peran guru maka proses belajar mengajar akan terganggu bahkan gagal. Oleh karena itu dalam manajemen pendididikan peranan guru dalam upaya keberhasilan pendidikan selalu ditingkatkan, kinerja atau prestasi kerja guru harus selalu ditingkatkan mengingat tantangan dunia pendidikan untuk menghasilkan kualitas sumber daya manusia yang mampu bersaing di era global.

Seorang guru dalam mengerjakan tugasnya dengan baik, seringkali ditentukan oleh penilaian terhadap kinerjanya. Penilaian tidak hanya dilakukan untuk membantu mengawasi sumber daya organisasi namun juga untuk mengukur tingkat efisiensi penggunaan sumber daya yang ada dan mengidentifikasi hal-hal yang perlu diperbaiki. Penilaian terhadap kinerja merupakan faktor penting untuk meningkatkan kinerja dan kepuasan kerja guru, bagian-bagian yang menunjukkan kemampuan guru yang kurang dapat diidentifikasi, diketahui sehingga dapat ditentukan strategi dalam meningkatkan kinerjanya.

Kepala sekolah merupakan seorang tenaga fungsional guru yang memberi tugas untuk memimpin suatu sekolah di mana terjadinya interaksi antara guru yang memberi pelajaran dan murid menerima pelajaran. Dalam suatu lembaga pendidikan, kepala sekolah bertanggung jawab atas kelangsungan pendidikan dan pengajaran, kelancaran proses pendidikan sangat tergantung kepada kepemimpinan kepala sekolah.

Kepala sekolah memegang peranan penting dalam perkembangan sekolah. Kepala sekolah bertanggung jawab dalam proses pembinaan para guru, pegawai tata usaha, dan pegawai sekolah lainya. Sebagai kepala sekolah, ia harus mengetahui, mengerti, dan memahami semua hal yang berkaitan dengan administrasi sekolah. Ia harus memahami potensi yang dimiliki oleh para gurunya, sehingga komunikasi dengan para guru dan karyawan sekolah akan membantu kinerjanya, terutama untuk menyelesaikan masalah yang di hadapi oleh sekolah yang di pimpinnya.

Dalam peranannya sebagai seorang pendidik, kepala sekolah harus mampu menanamkan, memajukan, dan meningkatkan nilai mental, moral, fisik dan artistik kepada para guru atau tenaga fungsional yang lainnya, tenaga administrasi (staf) dan kelompok para siswa atau peserta didik. Untuk menanamkan peranannya ini kepala sekolah harus menunjukkan sikap persuasif dan keteladanan. Sikap persuasif dan keteladanan inilah yang akan mewarnai kepemimpinan termasuk di dalamnya pembinaan yang dilakukan oleh kepala sekolah terhadap guru yang ada di sekolah tersebut.

Kepala sekolah sebagai edukator, supervisor, motivator yang harus melaksanakan pembinaan kepada para karyawan, dan para guru di sekolah yang dipimpinnya karena faktor manusia merupakan faktor sentral yang menentukan seluruh gerak aktivitas suatu organisasi, walau secanggih apapun teknologi yang digunakan tetap faktor manusia yang menentukannya.

Dalam fungsinya sebagai penggerak para guru, kepala sekolah harus mampu menggerakkan guru agar kinerjanya menjadi meningkat karena guru merupakan ujung tombak untuk mewujudkan manusia yang berkualitas. Guru akan bekerja secara maksimum apabila didukung oleh beberapa faktor diantaranya adalah kepemimpinan kepala sekolah.

Kepala sekolah sebagai pemimpin sekolah mempunyai tugas yang sangat berat dalam rangka meningkatkan kualitas sekolah. Guru sebagai salah satu komponen yang terpenting dalam pendidikan, terutama dalam hal mengatasi berbagai permasalahan yang berkaitan dengan peningkatan mutu pendidikan, dituntut untuk bisa menjadi guru profesional.

Profesionalisme guru tidak akan ada atau berjalan mulus tanpa adanya usaha-usaha yang dilakukan oleh kepala sekolah, sebab salah satu di antara cara guru agar bisa menjadi guru profesional adalah dengan adanya upaya-upaya yang dilakukan oleh kepala sekolah dalam rangka meningkatkan mutu guru.

Dari pengamatan awal permasalahan yang muncul tentang upaya kepala sekolah dalam meningkatkan kinerja guru, masih kurangnya pengawasan (controling) dari kepala sekolah terhadap kinerja guru, masih ada beberapa guru yang memiliki banyak tugas tambahan, 
sehingga tugas utama menjadi terganggu, masih ada guru yang belum menguasai IT, masih ada beberapa guru yang belum memenuhi standar kompetensinya sebagai guru, masih ada juga guru yang dalam melakukan pekerjaannya dalam mengajar memiliki rasa kurang bertanggung jawab. Selain itu ada juga guru yang sering bolos, tidak membuat administrasi mengajar setiap harinya dan tidak mematuhi perintah. Dengan adanya guru yang mempunyai kinerjarendah, akan sulit untuk mencapai hasil seperti yang diharapkan.

Berdasarkan uraian diatas, dapat kiranya diadakan penelitian tentang "upaya meningkatkan kinerja guru dalam mengajar melalui reward dan punishment oleh Kepala UPTD SD Negeri 01 Suliki Kecamatan Suliki ".

Dari latar belakang masalah yang telah diuraikan diatas dapat diidentifikasi beberapa masalah yaitu masih kurangnya pengawasan (controling) dari kepala sekolah terhadap kinerja guru, masih ada beberapa guru yang memiliki banyak tugas tambahan, sehingga tugas utama menjadi terganggu, masih ada guru yang belum menguasai IT, masih ada beberapa guru yang belum memenuhi standar kompetensinya sebagai guru, masih ada juga guru yang dalam melakukan pekerjaannya dalam mengajar memiliki rasa kurang bertanggung jawab. ada guru yang sering bolos, guru tidak membuat administrasi mengajar setiap hari, guru tidak mematuhi perintah dan sulit untuk mencapai hasil seperti yang diharapkan.

Agar permasalahan pada penelitian ini tidak menjadi luas, perlu adanya batasan-batasan sehingga ruang lingkup penenlitian menjadi jelas.

Berdasarkan latar belakang dan identifikasi masalah yang telah diuraikan diatas, maka permasalahan yang dibahas dalam penelitian ini yaitu upaya meningkatkan kinerja guru dalam mengajar melalui reward dan punishment oleh Kepala UPTD SD Negeri 01 Suliki Kecamatan Suliki.

Berdasarkan permasalahan yang telah dipaparkan pada latar belakang, identifikasi masalah dan pembatasan masalah diatas, secara umum penulis membuat rumusan masalah yaitu "apakah dengan reward and punishment oleh kepala UPTD mampu meningkatkan kinerja guru dalam mengajar di SD Negeri 01 Suliki Kecamatan Suliki?”.

Berdasarkan rumusan masalah yang telah dibuat, penulis menentukan tujuan penelitian ini yaitu : "untuk mengetahui apakah dengan reward and punishment oleh kepala UPTD mampu meningkatkan kinerja guru dalam mengajar di SD Negeri 01 Suliki Kecamatan Suliki".

Hasil penelitian ini dapat bermanfaat sebagai berikut:

1. Bagi kepala sekolah agar dijadikan acuan dalam menjalankan fungsinya sebagai pemimpin dan juga menjadi contoh bagi para bawahanya

2. Bagi guru-guru agar mengetahui kewajibanya sebagai tenaga pendidik dalam menjalankan tugasnya..

\section{METODE PENELITIAN Tempat Penelitian}

Penelitian ini dilaksanakan di UPTD SDN 01 Suliki Kecamatan Suliki. Alasan pemilihan lokasi ini dikarenakan peneliti merupakan kepala sekolah di sekolah tersebut, sehingga tidak mengganggu kegiatan mengajar dan mempermudahkan peneliti untuk mencari data dan informasi yang terkait dengan penelitian ini.

\section{Subjek dan Objek Penelitian}

Subjek dalam penelitian ini adalah guruguru di UPTD SD Negeri 01 Suliki Kecamatan Suliki yang berjumlah 8 orang.

Sedangkan yang menjadi objek penelitian adalah meningkatkan kinerja guru dalam pembelajaran melalaui reward and punishment di UPTD SD Negeri 01 Suliki Kecamatan Suliki.

\section{Waktu/ Lama Penelitian}

Penelitian ini dilaksanakan pada semester I tahun ajaran 2019/2020 dari bulan September sampai Desember dalam dua siklus, yaitu Siklus I dan Siklus II, masing - masing siklus dilakukan dua kali pertemuan. Siklus I pertemuan 1 selama bulan September, pertemuan 2 selama bulan Oktober, siklus II pertemuan 1 selama bulan November dan pertemuan 2 selama bulan Desember.

\section{Pentahapan Penelitian Tindakan}


Metode yang digunakan dalam penelitian ini adalah metode Penelitian Tindakan Sekolah (PTS). Penelitian tindakan sekolah merupakan “(1) penelitian partisipatoris yang menekankan pada tindakan dan refleksi berdasarkan pertimbangan rasional dan logis untuk melakukan perbaikan terhadap suatu kondisi nyata; (2) memperdalam pemahaman terhadap tindakan yang dilakukan; dan (3) memperbaiki situasi dan kondisi sekolah / pembelajaran secara praktis" (Depdiknas, 2008 : 11-12). Secara singkat, PTS bertujuan untuk mencari pemecahan permasalahan nyata yang terjadi di sekolah-sekolah, sekaligus mencari jawaban ilmiah bagaimana masalah-masalah tersebut bisa dipecahkan melalui suatu tindakan perbaikan.

Pendekatan yang digunakan dalam penelitian tindakan ini ialah pendekatan kualitatif. Artinya, penelitian ini dilakukan karena ditemukan permasalahan rendahnya tingkat kinerja guru dalam proses kegiatan belajar mengajar. Permasalahan ini ditindak lanjuti dengan cara menerapkan sebuah model pembinaan kepada guru berupa penerapan Reward dan Punishment yang dilakukan oleh kepala sekolah, kegiatan tersebut diamati kemudian dianalisis dan direfleksi. Hasil revisi kemudian diterapkan kembali pada siklus-siklus berikutnya.

Penelitian ini adalah penelitian tindakan model Stephen Kemmis dan Mc. Taggart (1998) yang diadopsi oleh Suranto (2000; 49) yang kemudian diadaptasikan dalam penelitian ini. Model ini menggunakan sistem spiral refleksi diri yang dimulai dari rencana, tindakan, pengamatan, refleksi, dan perencanaan kembali yang merupakan dasar untuk suatu ancangancang pemecahan masalah. Seperti yadiungkapkan oleh Mills $(200 ; 17)$ "Stephen Kemmis has created a well knownrepresentation of the action research spiral...". Peneliti menggunakan model inikarena dianggap paling praktis dan aktual. Kegiatan penelitian tindakan sekolah ini, terdiri atas beberapa tahap, yaitu : Perencanaan,Pelaksanaan, Pengamatan dan Refleksi

Langkah-langkah penelitian tindakan sekolah dapat digambarkan seperti gambar dibawah ini :

\section{Teknik Pengumpulan Data}

Teknik pengumpulan data dari penelitian tindakan sekolah ini adalah melalui data kualitatif yang diperoleh dari angket dan dokumentasi.

Angket adalah pertanyaan yang berbentuk tulisan yang disebarkan kepada guru UPTD SD Negeri 01 Suliki Kecamatan Suliki, yang menjadi sampel dengan memberi pertanyaan-pertanyaan yang berhubungan dengan yang dibahas peneliti.

Dokumentasi yaitu teknik pengumpulan data dengan mengadakan pencatatan terhadap data atau arsip yang dianggap penting bisa juga berfupa foto kegiatan yang dilaksanakan

\section{Instrumen Penelitian}

Instrumen penelitian yang digunakan dalam penelitian tindakan sekolah ini antara lainadalah :

1. Skala Penilaian

2. Lembar Pengamatan

3. Angket

\section{Teknik Analisis Data}

Analisa data yang digunakan dalam penelitian ini adalah analisa data kualitatif yang bersumber dari data primer maupun empiris. Melalui analisa data ini, dapat diketahui ada tidaknya peningkatan kinerja guru dalam kehadiran dikelas melalui pemberian reward dan punishment yang merupakan fokus dari penelitian tindakan sekolah ini.

Hasil dari penelitian ini, selain berbentuk cerita juga berbentuk angka dan bilangan. Jadi, dalam pengelolaan datanya juga digunakan analisis data kuantitatif. Analisis data kuantitatif ini dilakukan terhadap kinerja guru dengan menggunakan pendekatan persentase. Data hasil kinerja gurumdengan data kuantitatif dengan teknik persentase dengan prosedur sebagai berikut:

1. Hitung frekuensi dengan aturan skoring 


\begin{tabular}{lll}
\hline No & Pernyataan & Skor \\
\hline 1 & Selalu & 5 \\
2 & Sering & 4 \\
3 & Kadang & 3 \\
4 & Jarang & 2 \\
5 & Tidak Pernah & 1 \\
\hline
\end{tabular}

2. Cari persentase, dengan rumus

$$
P=\frac{F}{N} \times 100 \%
$$

Keterangan:

$\mathrm{P}=$ Persentase

$\mathrm{F}=$ Skor yang diperoleh

$\mathrm{N}=$ Nilai maksimal

Kriteria taraf keberhasilan ditentukan menurut Aderusliana (2009:6) sebagai berikut:

$\begin{array}{ll}80 \%-100 \% & \text { : Sangat baik } \\ 70 \%-79 \% & \text { : Baik } \\ 60 \%-69 \% & \text { : Cukup } \\ <59 \% & \text { : Kurang }\end{array}$

\section{HASIL PENELITIAN DAN PEMBAHASAN Hasil Tindakan}

Penelitian Tindakan Sekolah (PTS) ini dilaksanakan dalam dua siklus masing masing siklus terdiri dua kali pertemuan. Hali ini dikarenakan keterbatasan waktu yang tersedia, serta dengan dua siklus sudah penulis anggap cukup untuk peningkatan kinerja guru dalam kegiatan belajar mengajar.

\section{Siklus I}

Siklus I terdiri atas beberapa tahap, yaitu : Perencanaan, Pelaksanaan, Pengamatan dan Evaluasi, dan Refleksi.

\section{a. Perencanaan}

Perencanaan adalah langkah awal yang dilakukan oleh penulis saat akan memulai tindakan. Agar perencanaan mudah dipahami dan dilaksanakan oleh penulis yangakan melakukan tindakan, maka penulis membuat rencana tindakan sebagaiberikut :

1) Merumusan masalah yang akan dicari solusinya. Dalam penelitian ini masalahyang akan dicari solusinya adalah masih banyaknya guru yang memiliki kinerja yang rendah pada proses belajar mengajar.

2) Merumusan tujuan penyelesaian masalah/tujuan tantangan/tujuanmelakukan

inovasi/tindakan. Dalam penelitian ini penulis mengambil rencana untuk melakukan tindakan memberikan Reward dan Punishment kepada guru-guru untuk meningkatkan kinerja guru dalam proses belajar mengajar.

3) Merumusan indikator keberhasilan penerapan Reward dan Punishment dalam meningkatkan kinerja guru dalam proses belajar mengajar. Indikator keberhasilan penerapan tindakan ini penulis tetapkan sebesar $75 \%$, artinya tindakan ini dinyatakan berhasil bila $75 \%$ guru memiliki kinerja yang minimal dalam proses pembelajaran.

4) Merumusan langkah-langkah kegiatan penyelesaian masalah / kegiatan menghadapi tantangan / kegiatan melakukan tindakan.

Langkah-langkah yang diambil penulis dalam melakukan tindakan antara lain adalah melakukan sosialisasi kepada para guru mengenai penelitian yang akan dilaksanakan, serta menyampaikan tujuan dari penerapan tindakan yang dilakukan oleh penulis.

Kepada para guru disampaikan mengenai penerapan Reward dan Punishment yang akan diterapkan dalam penelitian ini. Pada siklus pertama ini, akan dipampang/ditempel di meja piket, diruang guru, dan diruang TU.

5) Mengidentifikasi metode pengumpulan data yang akan digunakan.

Metode pengumpulan data yang diambil oleh penulis merupakan data kualitatif melalui observasi, pengamatan mengenai kinerja guru dikelas pada kegiatan belajar mengajar.

6) Penyusunan instrumen pengamatan dan evaluasi.

Dalam pengambilan data, penulis menggunakan instrument berupa lembar observasi/pengamatan, skala penilaian serta angket yang disebarkan kepada guru.

$$
\text { b. Pelaksanaaa }
$$

Pelaksanaan penelitian tindakan sekolah ini dilaksanakan melalui beberapa kegiatan, antara lain :

1) Menyebarkan lembar angket kepada guru, lembar angket dapat dilihat pada lampiran.

2) Guru di minta untuk mengisi lembar angket dengan sejujur-jujurnya tanpa paksaaan

3) Setelah lembar angket diisi oleh guru, lembaran tersebut dikumpulkan dan 
dilakukan pengamatan terhadap lembaran tersebut.
Dari hasil pengamatan lembar angket didapat data sebagai berikut :

c. Pengamatan dan evaluasi

Tabel 2. Hasil Pengamatan Kinerja Guru Siklus I

\begin{tabular}{cccccc}
\hline No & Nama Guru & \multicolumn{2}{c}{ Pertemuan 1 } & \multicolumn{2}{c}{ Pertemuan 2 } \\
& & Total & Rata-Rata $(\%)$ & Total & Rata-Rata (\%) \\
\hline 1 & Guru 1 & 72 & 55,38 & 78 & 60 \\
2 & Guru 2 & 75 & 57,69 & 77 & 59,23 \\
3 & Guru 3 & 78 & 60 & 81 & 62,31 \\
4 & Guru 4 & 78 & 60 & 84 & 64,62 \\
5 & Guru 5 & 76 & 58,46 & 84 & 64,62 \\
6 & Guru 6 & 77 & 59,23 & 85 & 65,38 \\
7 & Guru 7 & 76 & 58,46 & 86 & 66,15 \\
8 & Guru 8 & 76 & 58,46 & 83 & 63,85 \\
& Rata-rata & & 58,46 & & 63,27 \\
\hline
\end{tabular}

Dari table di atas dapat disimpulkan bahwa kinerja guru meningkat dari pertemuan pertama ke pertemuan kedua. Rata-rata yang dicapai guru pada pertemuan 1 yaitu $58,46 \%$ dengan kategori kurang, dan meningkat pada pertemuan 2 menjadi 63,27\% dengan kategori cukup.

Persentase capaian guru pada siklus I dapat juga digambarkan pada diagram di bawah ini :

Diagram 1. Persentase capaian guru pada siklus I

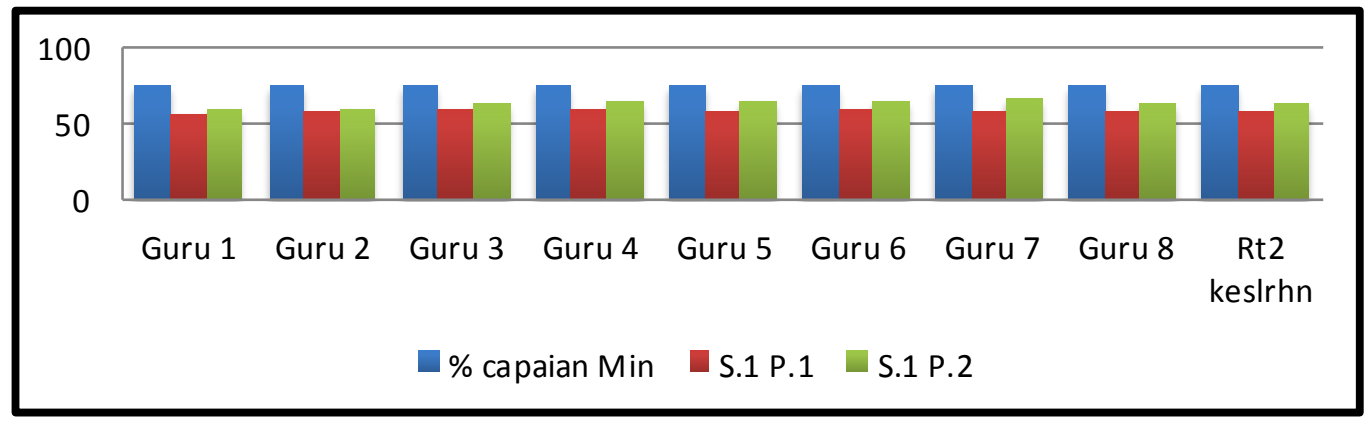

Berdasarkan diagram diatas dapat disimpulkan bahwa, dari 8 (delapan) guru, yang mampu meningkatkan kinerja dalam pembelajaran melalaui reward and punishment oleh kepala sekolah pada siklus I sudah semua guru, namun belum mencapai nilai minimal yang ditetapkan yaitu 75 , jadi peneliti berkesimpulan harus diadakan penelitian atau tindakan lagi pada siklus berikutnya atau siklus kedua.

\section{d. Observasi}

Setelah selesai satu siklus maka diadakan refleksi /observasi mengenai kelemahan atau kekurangan dari pelaksanaan tindakan pada siklus pertama. Refleksi dilaksanakan bersamasama kolaborator untuk menentukan tindakan perbaikan pada siklus berikutnya. Dari hasil refleksi dapat diambil suatu kesimpulan bahwa perlu penerapan Reward dan Punishment yang lebih tegas lagi daripada siklus pertama.

\section{Siklus II}

Siklus II terdiri atas beberapa tahap, sama seperti siklus I yaitu : Perencanaan, Pelaksanaan, Pengamatan dan Evaluasi, dan Refleksi.

\section{a. Perencanaan}

Dari hasil refleksi pada siklus pertama, peneliti merencanakan untuk melakukan tindakan Reward dan Punishment yang lebih tegas dibandingkan dengan siklus pertama.

Peneliti merencanakan untuk mengumumkan hasil observasi mengenai tingkat kinerja guru dalam proses belajar 
mengajar, hal ini terlebih dahulu disosialisasikan kepada semua guru pada saat refleksi siklus pertama.

\section{b. Pelaksanaan}

Pelaksanaan penelitian pada siklus II tidak jauh berbeda dengan siklus I.

Pelaksanaan penelitian tindakan sekolah ini dilaksanakan melalui beberapa kegiatan, antara lain :

1) Menyebarkan lembar angket kepada guru Lembar pengamatan dapat dilihat pada lampiran.

Tabel 3. Hasil Pengamatan Kinerja Guru Siklus II

\begin{tabular}{cccccc}
\hline No & Nama Guru & \multicolumn{2}{c}{ Pertemuan 1 } & \multicolumn{2}{c}{ Pertemuan 2 } \\
& & Total & Rata-Rata (\%) & Total & Rata-Rata (\%) \\
\hline 1 & Guru 1 & 92 & 70,77 & 110 & 84,62 \\
2 & Guru 2 & 88 & 67,69 & 105 & 80,77 \\
3 & Guru 3 & 90 & 69,23 & 102 & 78,46 \\
4 & Guru 4 & 95 & 73,08 & 104 & 80,00 \\
5 & Guru 5 & 91 & 70,00 & 105 & 80,77 \\
6 & Guru 6 & 96 & 73,85 & 104 & 80,00 \\
7 & Guru 7 & 94 & 72,31 & 103 & 79,23 \\
8 & Guru 8 & 95 & 73,08 & 102 & 78,46 \\
& Rata-rata & & 71,25 & & 80,29 \\
\hline
\end{tabular}

Dari table di atas dapat disimpulkan bahwa kinerja guru meningkat dari pertemuan pertama ke pertemuan kedua. Rata-rata yang dicapai guru pada pertemuan 1 yaitu $71,25 \%$ dengan
2) Guru di minta untuk mengisi lembar angket dengan sejujur-jujurnya tanpa paksaaan

3) Setelah lembar angket diisi oleh guru, lembaran tersebut dikumpulkan dan dilakukan pengamatan terhadap lembaran tersebut.

$$
\text { c. Pengamatan dan evaluasi }
$$

Dari hasil pengamatan lembar observasi didapat data sebagai berikut :

\section{Diagram 2. Persentase Capaian Guru Siklus II}

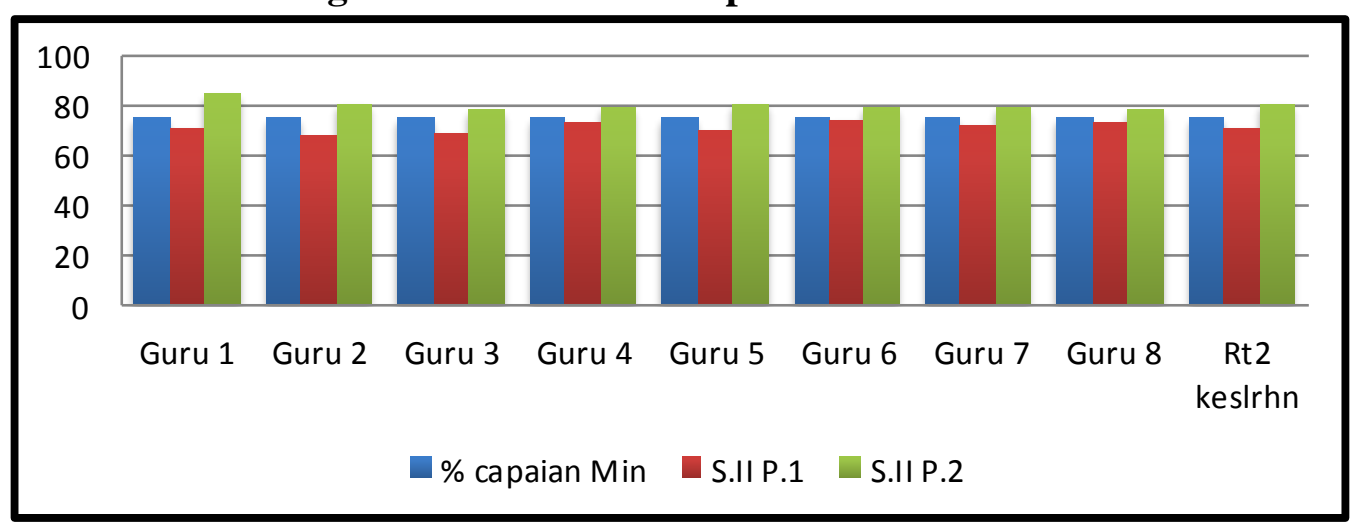

Berdasarkan diagram diatas dapat mampu meningkatkan kinerjanya dalam disimpulkan bahwa, dari 8 (delapan) guru, sudah seluruh guru mampu meningkatkan kinerja dalam pembelajaran melalaui reward and punishment oleh kepala sekolah, dapat dilihat tidak ada lagi capaian kinerja guru dibawah $75 \%$. Dengan artian sudah seluruh guru

kategori baik, dan meningkat pada pertemuan 2 menjadi 80,29\% dengan kategori sangat baik.

Persentase capaian guru pada siklus II dapat juga digambarkan pada diagram di bawah ini : 
Dari hasil observasi dan data yang diperoleh, peneliti mengambil kesimpulan bahwa tindakan yang dilaksanakan pada siklus kedua dinyatakan berhasil, sudah seluruh guru mampu mencapai nilai minimal yang telah ditetapkan.

\section{KESIMPULAN}

Berdasarkan analisis data, dari penelitian ini dapat ditarik kesimpulan bahwa penerapan Reward dan Punishment efektif untuk meningkatkan kinerja guru dikelas pada kegiatan belajar mengajar.

Data yang diperoleh menunjukan bahwa setelah diadakan penerapan tindakan berupa Reward dan Punishment, pada siklus I kinerja guru sudah meningkat namun masih belum mencapai nilai minimal yang ditetapkan dan guru belum mampu meningkat kinerjanya dalam pembelajaran. Namun, setelah preward and punishment lebih ditingkatkan maka pada siklus II sudah seluruh guru mampu meningkatkan kinerjanya.

Penerapan Reward dan Punishment dapat meningkat kinerja guru dalam proses belajar mengajar di UPTD SD Negeri 01 Suliki Kecamatan Suliki

\section{DAFTAR PUSTAKA}

Abdullah, Munir. 2008. Menjadi Kepala Sekolah Eektif. Jogjakarta:Ar-Ruzz Media.

Arikunto, Suharsimi. Manajemen Pengajaran Secara Manusiawi. Jakarta: Rineka Cipta, Cet,VI.

Cholid, Narbuko.2007. Metodologi Penelitian. Jakarta:Bumi Aksara.

Danim S. 2002. Inovasi Pendidikan. Bandung: Pustaka Setia.

David,freed R. 2006. Manajemen Strategi. Jakarta:Salemba Empat.

Djamah, S. 2004. Prestasi Belajar dan Kompetensi Guru. Surabaya: Usaha Nasional, Cet. IV.

Imron.Ali. 1993. Pembinaan Guru Di Indonesia. Jakarta:Pustaka Jaya.

Kementrian Pendidikan Nasional. 2013. Penilaian Kinerja Guru , Jakarta: Direktorat Tenaga Pendidikan Direktorat
Jendral Peningkatan Mutu Pendidikan dan Tenaga Kependidikan.

M. Ngalim Purwanto. 2006. Administrasi dan Supervisi Pendidikan. Bandung: Remaja Rosdakarya.

Mulyasa. E. 2007. Menjadi Kepala Sekolah Profesional. Bandung:Remaja Rosdakarya.

Moh.Uzer Usman. 1995. Menjadi Guru Profesional. Bandung: Remaja Rosda Karya.

Moleong, lexy J. 2010. Metodologi Penelitian Kuantitatif. Bandung: Remaja Rosda Karya

Mudrajad Kuncoro. 2006. Strategi Bagaimana Meraih Keunggulan Kompetitif, Jakarta:Erlangga.

Mulyono. 2008. Manajemen Administrasi \& Organisasi Pendidikan. Jogjakarta: Ar Ruzz Media.

Saefudin Saud. 2009. Pengembangan Profesi Guru. Bandung: Alfabeta.

Saiful Sagala. 2009. Manajemen Strategi dalam Peningkatan Mutu Pendidikan. Bandung:Alfabeta.

Sardiman AM. 2000. Inteaksi dan Motivasi Belajar Mengajar. Jakarta:Raja Grafindo Persada.

Sarlito Sarwono, W. 2012. Pengantar Psikologi Umum, (Jakarta:Raja Grafindo Persada.

Sondang P.Siagian. 2001. Manajemen Strategi. Jakarta:Bumi Aksara.

Sugiyono. 2011. Metode Penelitian Kuantitatif, Kualitatif, Dan R\&D, Bandung: Alfabeta

Sulistyorini. 2001. Hubungan antara Keterampilan Manajerial Kepala Sekolah Madrasah dan Iklim Organisasi dengan Kinerja Guru. Jakarta : Media Ilmu.

Suryabrata, Sumadi. 2005. Metodologi Penelitian. Jakarta, PT Raja Grafindo Persada,

Sutadipura. 2004. Kompetensi Guru dan Kesehatan Mental. Bandung, Angkasa.

Tim Penyusun Kamus Pusat Bahasa. 2002. Kamus Besar Bahasa Indonesia. Jakarta:Balai Pustaka.

Tim penyusun, Undang-Undang Nomor 14 Tahun 2005 tentang Guru dan Dosen (Jakata: Sinar Grafika, 2006 ) 
Undang-undang RI No.14 Tahun 2005, Tentang

Guru dan Dosen(Penghargaan,pasal 36)

Undang-undang RI No.20 tahun 2003

Tentang Sistem Pendidikan

Nasional,(Jakarta: Direktorat Jendral

Pendidikan Dasar dan Menengah, Bagi

Proyek Penilaian Hasil Belajar Tahap

Akhir Nasional, 2003

Undang-Undang RI Nomor 18 tahun 2002

W. Mantja. 2005. Manajemen Pendidikan dan

Supervisi Pengajaran. Malang:Winika Media.

Wahjosumidjo. 1999. Kepemimpinan Kepala Sekolah. Jakarta:Rajagrafindo Persada

Widyastusi, Yeni. 2014. Psikologi Sosial. Yogyakarta:Graha Ilmu 